\title{
Adaptive learning, technological innovation and livelihood diversification: the adoption of pound nets in Rio de Janeiro State, Brazil
}

\author{
Carlos Julián Idrobo ${ }^{*}$ and lain J Davidson-Hunt
}

\author{
* Correspondence: umidrobo@cc. \\ umanitoba.ca \\ Natural Resources Institute \\ University of Manitoba, Winnipeg, \\ R3T 2N2, Canada
}

\begin{abstract}
This paper examines the adoption of a technology to appropriate an ecologically constrained resource within the context of a restructuring fisheries sector utilising the conceptual lenses of adaptive learning and practice. Participant observation and semi-structured interviews were undertaken in the coastal community of Ponta Negra, Paraty, Rio de Janeiro, Brazil, from May 2010 to March 2011. The materials collected were translated and transcribed into English and then manually coded. Through a restorying process the English transcripts were developed into an analytical narrative that described the process of the adoption of pound nets and how this initiated a process of social differentiation between fishing households. The pound net technology constituted a new field of practice that both created and constrained opportunities for livelihood diversification. In this case, individual adaptations made to diversify household economies initiated a cascading process of social differentiation within a coastal community.
\end{abstract}

\section{Introduction}

The cercos flutuantes are a type of stationary fishing gear related to the Japanese pound net. Over the course of the last century, this type of fishing technology has become the main fishery in small coastal communities along SE Brazil, especially in the São Paulo and Rio de Janeiro States (Brito 2003; Diegues and Nogara 2005; Vianna 2008). Currently the cercos are an important source of employment and fish resources for these small communities and have been the basis of the local economy for many decades. The economic stability provided by cercos, however, is diminishing because of the depletion of fish stocks associated to the modernisation of industrial fishing fleets operating in the area (Diegues 2002). Some people in Ponta Negra have begun considering tourism as a means to diversify their livelihood portfolio. However, a limited ability to supply adequate infrastructure for domestic and international tourists, and to advertise products and services, creates structural limitations that hinder many Ponta Negra fishers from entering the tourism sector.

The objective of this paper is to analyse the context and consequences of the adoption of the cerco fishing technology in Ponta Negra. We use the fishing technology as a focal point to trace the emergence of this technology within the regional economy and document the web of social relations and structural changes it engendered within the 
community. The case of Ponta Negra tells the story of a livelihood diversification process, marked by the adoption of the cercos, which is interwoven into a context of growth, modernisation and restructuring of a regional fishing economy. We examine this process through the everyday practice of fishers from the early stages of learning to utilise the technology, through its implementation in Ponta Negra, to the use of monetary surpluses gained by households with this technology to invest in other diversification strategies. This conceptual framework allows us to consider the role of individual learning and innovation in the process of livelihood diversification while tracing the emergence of structures, which result from an exercise of agency, and then refract back upon the opportunities for future livelihood diversification.

Livelihood diversification processes have been a subject of study in rural development, including in the context of small-scale fishing communities (Béné et al. 2003; Coulthard 2008; Ellis 1998, 2000), and have been adopted as a paradigm for policy intervention (Ellis and Allison 2004). Ellis (2000: 15) defines livelihood diversification "as the process by which rural households construct an increasingly diverse portfolio of activities and assets in order to survive and to improve their standard of living". There is general agreement that diversification is of benefit to people living in poverty by reducing the vulnerability that comes with dependence on a single set of resources or a single economic sector (Béné 2011; Ellis and Allison 2004; Marschke and Berkes 2006).

Livelihood diversification processes have been classified according to two main outcomes (Béné et al. 2003): diversification for survival and diversification for accumulation. While 'diversification for survival' is a reactive strategy followed by economically disadvantaged households as a response to shocks and stresses, 'diversification for accumulation' is a proactive strategy pursued by better-off households in anticipation of both crises and new opportunities. However, the relationships between them are not always clear. Livelihood diversification processes are complex and not uniform; they are facilitated and/or hindered by local circumstances, social status, acceptance of new opportunities, and access to available resources, among other factors (Coulthard 2008).

In this paper, we use an adaptive learning perspective (Davidson-Hunt 2006) to illustrate how individual adaptation associated with technological innovation is nested in the political economy of a place, grounded in ecological limitations, and reverberates into collective dimensions of social differentiation, access to natural resources and livelihood diversification opportunities. An adaptive strategy, in such a case, may position innovators with increased opportunities for diversification and lead to social differentiation within a community.

Adaptive learning is rooted in conceptual frameworks that consider the dialectical relationships between agency and structure and the historical conditions and processes of their interaction (Bourdieu 1977; Giddens 1979). In this context, practice plays a key role as it carries forward "dispositions or subconscious understandings of the world that evolve historically and position individuals within particular social classes or at points in a culture's social structures" (Bourdieu 1977 adapted in Jones and Murphy 2010).

Adaptive learning is tempered by Bourdieu's theory of practice and its concepts of habitus and field (Bourdieu 1977). Habitus conveys the underlying principles that generate and coordinate individual practice within a given cultural context or social group. Drawing upon habitus, practice takes place by inducing the active presence of past experiences and existing relations that operate on each individual as schemes of perception, 
thought and action (Bourdieu 1977). Such schemes are shaped by and shape the field. Field represents "a social arena within which struggle or manoeuvres take place over specific resources or stakes and access to them" (Bourdieu interviewed by Jenkins 2002: 84). Field constitutes the space of action where the individual agent develops a habitus relative to a structure that situates and informs everyday practice, acquiring resources relative to those structures (Bourdieu 1977).

An approach rooted in the theory of practice reveals how individual adaptations are linked to broader socio-economic and historical contexts and, therefore, allows an understanding of the social differentiation processes related to the adoption of cercos as a technological innovation. While adaptation occurs at the individual level, it has led to the emergence of a new field of practice and, with it, new institutions that govern access to natural resources. The ecological context is such that there are only a limited number of sites along the coast, and near to the community, resulting in a condition in which cerco sites are a scarce resource linked to a specific set of social and economic relations that influence how sites are appropriated and benefits distributed. As such, the cercos constitute a field that has structured social-economic relations in Ponta Negra through a process of livelihood diversification and in turn created new opportunities for subsequent diversification, for some, while constraining the opportunities for others.

Studies of human adaptation and adaptive learning have highlighted the central role of individual learning in adaptation processes (Davidson-Hunt and Berkes 2003; DavidsonHunt 2006; Ellen 1982). Processes of individual adaptation have also been suggested as an important focus in efforts to understand local responses to social-ecological change in the absence of human capacities and financial resources for institutional adaptation (Coulthard 2008). In this case, adequate policies and incentives to mitigate the effects of declining fish stocks and changing regional economies are conspicuously absent (Diegues 2002). However, while such studies have looked at the mechanisms and process by which individuals adapt to a changing environment, they have not considered how adoption of a technological innovation may reverberate through a community, causing social differentiation processes. To draw upon an old metaphor, does the rising tide of livelihood diversification result in the lifting of all boats?

We begin our consideration of this question by first presenting the study area background (Figure 1), followed by a review of methods utilised in the research and then a description of the cerco flutuante fishing technology. Turning to the results of the research we recount the experience of cercos flutuantes in Ponta Negra in three movements. The first tells the history of the cercos in Ponta Negra according to the living memory of key community members. This section describes Ponta Negra livelihoods and its relations with the regional economy before the arrival of the cercos in the community (1940s - 1970s), during the period of adoption of the cercos (1970s - 1990s), and the contemporary dynamics of the cercos and their relation to the emergence of tourism in the community (1990s - present day). The second sections deals with current dynamics surrounding the cercos in terms of territoriality and ownership. This section reviews how community members appropriated cerco fishing spots and how that ownership changed over time. The third section deals with current livelihood diversification patterns as they relate to cerco ownership. We conclude this paper with a discussion of the consequences of adopting a fishing technology in a limited ecological setting on social relations and structures of Ponta Negra, and the implications of using this technology on current livelihood diversification patterns. 


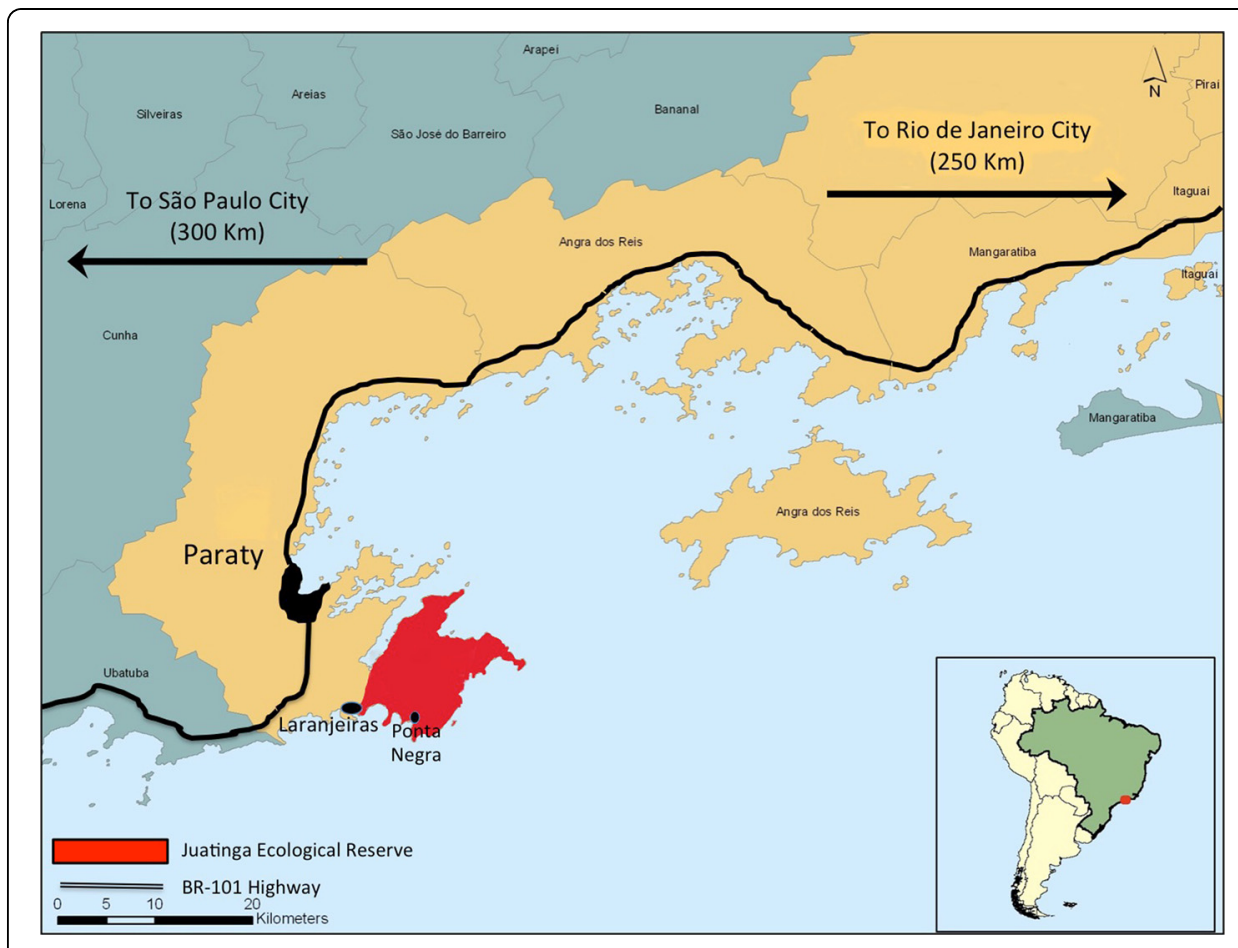

Figure 1 Study area and regional context.

\section{The community of Ponta Negra}

This study is located in the community of Ponta Negra. Situated on the coast in one of Brazil's last remaining expanses of Atlantic Forest, the nearest urban centre to Ponta Negra is Paraty, a small tourist city with a resident population of approximately 40,000. The current population of Ponta Negra is 158 ( 82 males and 76 females) of whom 100 are children (under 18 years old). The main economic sectors in Ponta Negra are fishing, shifting agriculture, forest products collection, tourism and local building construction. Although tourism has grown into an important economic sector over the last twenty years, the cerco fishery remains the largest employer in the community and one of the linchpins of the local economy. Alongside these activities, people in Ponta Negra receive federal government subsidies linked to national policies to reduce illiteracy (that is, Bolsa da Familia) as well as retirement pensions from the Ministry of Fisheries. Currently the school children in Ponta Negra only receive education up to the fourth level of elementary school and most of the adults in the community are functionally illiterate. There is no grocery store in Ponta Negra. Community members have to buy all of their supplies in Paraty. There are only three restaurants, which are geared towards the tourist market and are economically inaccessible to the local residents.

Ponta Negra is an isolated community located within the Juatinga Ecological Reserve. Reserve management authorities have limited natural resource-related activities, such as shifting agriculture and hunting, and infrastructure development, especially if it is related to the tourism sector. Furthermore, there is currently no electricity in Ponta Negra and the water system is comprised of a basic network of rubber hoses that take untreated water from the streams that cross the community. The shacks on the beach, 
the only available fish storage facilities, preserve the catches in Styrofoam coolers using ice sent from Paraty by fish buyers. There is no direct road access to Ponta Negra. The most convenient way of reaching the community from Paraty requires a one-hour trip by public transit and then crossing a gated community, called Laranjeiras, where a small harbour can be accessed. From Laranjeiras it takes 30 minutes to reach Ponta Negra via fibreglass skiffs powered with 15 to $25 \mathrm{HP}$ outboard motors. The trip takes from two to four hours in total depending on the availability of transportation and weather conditions. The strict security regulations in place around Laranjeiras have become a critical factor influencing the infrastructure required by community members to move between Paraty and Ponta Negra. The security procedures can delay transit through the gated community significantly. Community members can avoid the passage through Laranjeiras by using a very rudimentary $8 \mathrm{~km}$-long trail through the forest. However, it is impossible to travel this trail transporting goods (such as fish for trade) or any substantial amount of basic supplies for household consumption.

\section{Methods}

The research for this paper was undertaken between May 2010 and March 2011 in Ponta Negra. In order to tell the story of cerco adoption and its implications for Ponta Negra, knowledgeable people who were willing to participate in this research were sought. Six respected community members were identified and interviewed. They provided accounts of the recent history of the community that became the central source of data for this article.

These interviews were conducted in a fluid, semi-structured manner, employing open-ended questions. A semi-structured interviewing strategy was used because it allowed us to explore themes in an ordered but flexible way (Hay 2005). The themes covered during these interviews included remarkable features of every day life during different life stages (childhood, early adulthood, late adulthood) and experiences of key events in the community and regional context, such as the arrival and diffusion of the cercos, industrial fishing and its relations with the community, the emergence of local tourism, the effects of real estate developments (Condominio Laranjeiras), and the declaration of the Juatinga Ecological Reserve. Sample questions included: "how was life in Ponta Negra when you were a child?"; "when did you start fishing?"; and, "what do you know about the first cercos in the community?"

Semi-structured interviews with relevant stakeholders, including current cerco owners (6), cerco workers (13), fish buyers (2), and the superintendent of the Juatinga Ecological Reserve (1), provided supporting data about local and extra-local dynamics associated with the cerco fishery and the history of local livelihoods. The interviews with the current cerco owners and workers provided accounts of the dynamics of the cercos, their particular history, payment system, and the influence of the cercos on current livelihood diversification patterns in Ponta Negra. The interviews with fish buyers provided accounts of the structural limitations of fish trade. Finally, the interview with the superintendent of the Juatinga Ecological Reserve provided accounts of the relations Ponta Negra people have with the protected area and impacts of tourism development in the region. In addition to the interviews, available documentation and literature about the dynamics of the regional fishing economy from the 1920 s to the present day were reviewed. Data collection also included participation in the cerco fishery, other natural resource-related activities and other aspects of everyday life. 
The interviews were originally conducted in Portuguese, then interpreted and transcribed into English, and manually coded according to the original interview themes and emergent patterns found in the interviews. Narrative restorying was employed as the analysis strategy (Ollerenshaw and Creswell 2002; Tierney 2009). Restorying refers to the process of analysing data from interviews and field notes to understand lived experiences and then retelling that story from a particular perspective (Ollerenshaw and Creswell 2002). Key events in the history of the community identified through the data gathering techniques discussed above provided the structure of the results section of this paper, which we organised in chronological order. The review of secondary material allowed us to intertwine and re-story the local narratives about the history of local livelihoods within the history of the regional economy (Ollerenshaw and Creswell 2002).

This research was conducted with the approval of the University of Manitoba's Research Ethics Board (Protocol J2010:047). During data collection, time limitations and other responsibilities of community members were respected at all times. Research collaborators provided their consent to be identified by name.

\section{Description of the cercos flutuantes}

The cercos flutuantes are a type of stationary fishing gear that evolved from the Japanese pound net (Von Brandt 1972). Cercos flutuantes are relatively large, tri-dimensional fish trap systems into which fish enter voluntarily, but are hampered from leaving (von Brandt 1972; Figure 2). A cerco consists of a net leader (caminho in Portuguese) that is anchored to the shore and directs fish towards the oval-shaped entrapment area (casa), where fish circle until they are collected. The entrapment area is shaped like a basket and has a mouth (boca) and a collecting area (ensacador). The mouth is the opening through which the fish enter and is

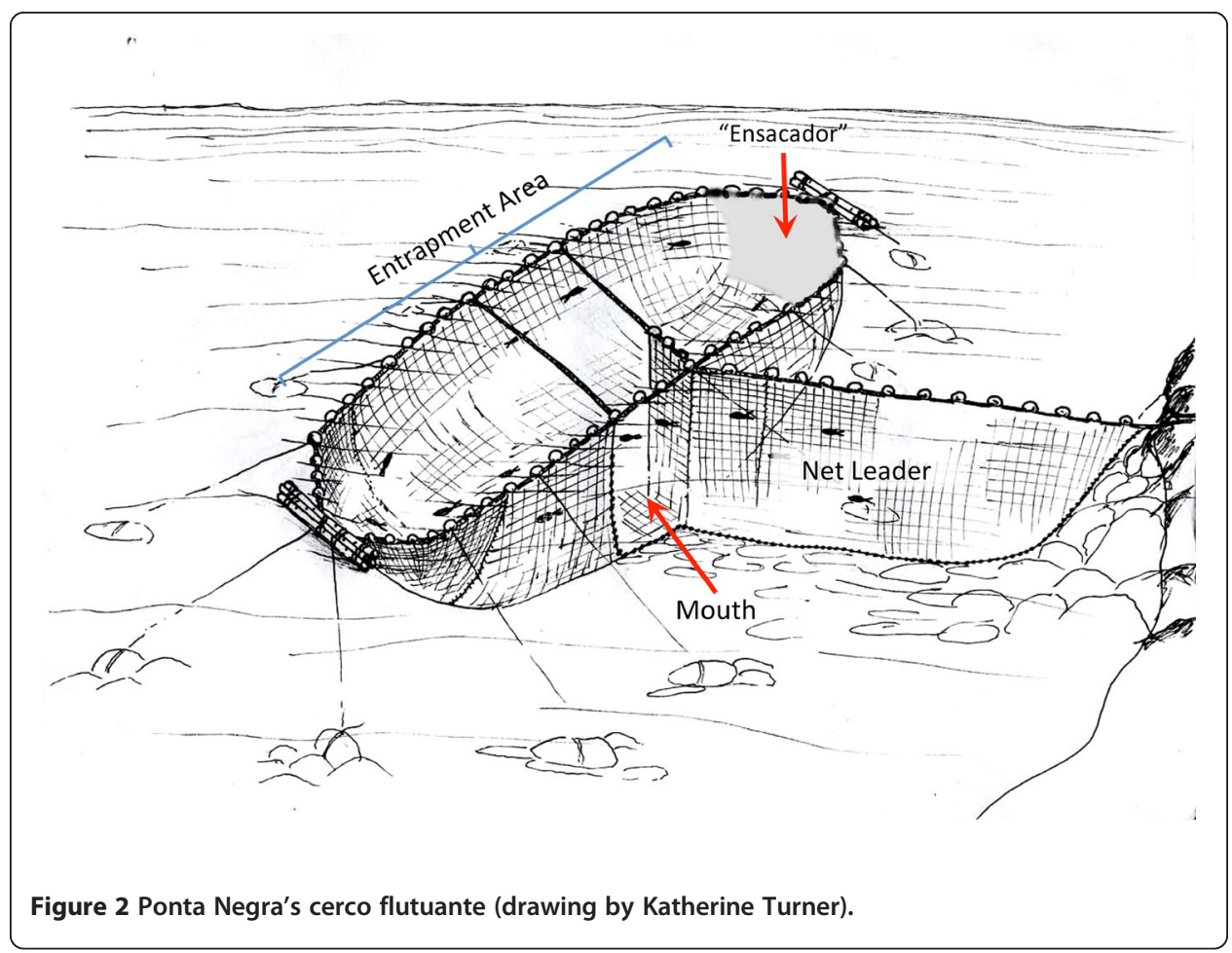


located at the junction of the net leader and the entrapment area. As a general pattern in Ponta Negra, the cercos are located on the west side of Ponta Negra Bay and Antigos Bay and their mouths are landwards. The only exception to this is the cerco 5, which opens seaward. All the cercos have the fish collecting area at the end of the entrapment area, located on the side of the net that points to the sea. At this end, the fish are gathered and transferred to the canoes. Both the net leader and the entrapment area are anchored to heavy rocks (approx. 300Kg), which are fastened to long cords (between $30 \mathrm{~m}$ and $50 \mathrm{~m}$ ). This anchoring system functions to keep the tension and shape of the cerco, especially during bad weather.

Each cerco, including both the net leader and the entrapment components, varies in size depending on its location and the preferences of the owner. On average, the net leader is $50 \mathrm{~m}$ long, the entrapment area diameter is $70 \mathrm{~m}$, and the depth is $15 \mathrm{~m}$. The entrapment area and the net leader are made with net that is woven by community members with industrial nylon used for car tire casings. The nets have approximately $11 \mathrm{~cm}$ mesh size, which is standard for all the cercos in the community and responds to a similar pattern shared by all the net makers. The origin of this pattern is neither recorded in documents nor existent within the memory of fishers. The collecting area is made with old net from purse seiners and has a $2 \mathrm{~cm}$ mesh size.

\section{A history of the cercos in Ponta Negra}

We re-story a history of the cercos in Ponta Negra according to three periods. The first period is before the cercos (1940s - 1970s), when the local livelihoods were structured around shifting agriculture and community members lived through the first manifestations of the rise and modernisation of the regional fishing economy. The second period corresponds to the adoption of the cercos (1970s - 1990s). This period sees the start of social differentiation processes and subsequent restructuring of the local livelihoods. The local economy shifts from being based in the land to the sea. The third period deals with the contemporary dynamics of the local livelihoods (1990s - 2011). This period shows the consequences of the restructuring of the regional fishing economy, regional integration and arrival of tourism developments. During this period community members experience increased limitations for fish trade and growing opportunities in the tourism economy.

\section{Local livelihoods before the cercos (1940s - 1970s)}

Shifting Agriculture and Fishing for Household Consumption and Petty Exchange Before the introduction of the cercos in Ponta Negra, fishing activities were not a primary element of the local livelihoods and economy. Ponta Negra livelihoods relied mainly upon shifting agriculture and other associated harvesting activities, such as hunting and picking forest fruits. These agricultural activities structured everyday life and influenced the connections the community had with the outside world. Shifting agriculture and harvesting activities were the basis of local nutrition and economic income, as their outputs were consumed locally and traded both locally and regionally. 
A 70 year-old elder from the community, provides a glimpse of the relations that people from the community had both with land and sea before the arrival of the cercos in the community:

When I was a child we had lot of work in the roça [shifting agriculture plot]. We used to plant many things there, but we did not have the means we have today to harvest and commercialise things from the sea. [....] I used to produce manioc and banana. Boats from Rio de Janeiro City used to come here to pick up the items we used to produce (Taken from the interview with Nelson, October 22, 2010).

While agriculture provided the core for the domestic economy of Ponta Negra households, fishing was nevertheless an important secondary contributor. However, the technologies people used to catch the fish as well as the ways by which fish were traded, preserved and eaten were different. People used to fish mostly with hand lines cast either from shore or from small dugout canoes and surface gillnets (meijoada). Other techniques, such as harpooning from the shoreline and small bamboo traps (covos), were also occasionally used. Fish, at this time, were consumed by the household and shared with others in the community. A small quantity of the catch was traded in nearby urban centres, such as Ubatuba (São Paulo State) and Paraty (Taken from the interview with Nelson, October 22, 2010).

The fish destined for sale and storage was gutted, soaked in brine and sun-dried on the beach. Dried fish, as community members recalled, was an important part of people's diets. Boiled fresh fish and banana (known as "azul marinho") were also described as a frequent part of the local diet.

Even though fish is still important in the local diet, the aforementioned ways of eating fish are not as prevalent. These recipes belong to a past that people talk about with nostalgia as contemporary access to money and grocery stores has introduced other staples and with them new tastes: deep-fried fish, rice and beans now feature as the main staples in the community:

Ponta Negra was very poor back then [approximately 40 years ago]. We used to eat beans, rice and dry meat only once a year; they were a treat for us. Our main food items were fish and green banana. [...] Only during Christmas or Carnival people went to the city and spent some money on special foods, just to eat something different (Taken from the interview with Nadirema, October 23, 2010).

The amount of fish sold and the frequency of visits to the nearby urban centres were constrained by the isolation of Ponta Negra. Better access to the urban centres over the last 40 years was one of the changes that improved their lives in recent decades:

Even though there was much more fish than what we have today, there was not a lot of commercial fishing going on in Ponta Negra. Why could we not do so? It was because we had no way to transport fish products. [Commercial] fishing did not exist because we had no buyers for our catches. We used to catch the fish, dry it and pack it in a canoe and take to Ubatuba or Paraty, so we could sell the dried fish there. [...]. These days you 
bring the fish to the beach and deliver it directly to the buyer (Taken from the interview with Nelson, October 22, 2010).

Rise and Growth of Regional Industrial Fishing National and regional changes associated with the promotion and steady growth of the fishing industry in the first part of the 1900s brought important changes to coastal livelihoods is SE Brazil (Diegues 1983). These processes marked the transformation of fishing practice and economy from subsistence to commercial (Diegues 2004). In Ponta Negra, these regional changes were mainly manifested in new markets for the local catches and new job opportunities for community members to work as crewmembers in the growing industrial fishing fleets (Taken from the interview with Nelson, October 22, 2010). These changes in the fishing industry affected most, if not all, the small coastal communities in the states of São Paulo and Rio de Janeiro (Diegues 1983; Nogara and Diegues 2005; Vianna 2008).

As large-scale fishing became more prominent regionally, nationally, and even internationally, boats from nearby urban centres began to buy fresh fish in Ponta Negra:

When I was 14 years old [circa 1954] I remember many fishing boats from Rio de Janeiro and Paraty, and even from Portugal, came around here. These boats used to come to fish and buy fresh fish ('peixe verde'). There were no cercos back then; we mainly fished with hand lines and gillnets (Taken from the interview with Nelson, October 22, 2010).

The growth of large-scale fisheries in SE Brazil was also accompanied by job opportunities for residents in small coastal communities (Diegues 1983; Vianna 2008); Ponta Negra was not an exception. The jobs provided by this growing industry became an important source of the local income (Taken from the interview with Antonio, September 20, 2010; Dominogos, September 16, 2010). The oldest community members in Ponta Negra started fishing in large-scale fishing vessels as young adults (between 15 and 20 years of age), during the 1950s and 1960s. Working in large-scale fishing boats, mainly sardine seiners, provided workers with extra income, which was invested in improving their living conditions and quality of life in general:

Back in the day all the houses in the community were made of wattle and daub (pau pique) and thatched roofs (zapé). After people left to work in Santos [São Paulo State] and other places in large-scale fishing boats there was money available to buy better construction materials. Life improved many times from how it was when I was a little boy. Access to better jobs and to more money has been responsible for the improvement of our lives (Taken from the interview with Nelson, October 22, 2010).

In 1967, the Brazilian government, through the newly created Department for Fisheries Development (Superintendência do Desenvolvimento da Pesca), developed a series of policies and economic incentives to enhance commercial fisheries (Diegues 2002). These incentives focused on the growth and modernisation of industrial fishing fleets by increasing the number of fishing vessels and equipping them with more efficient technologies (Diegues 2002). These industrial-fishing fleets were mainly based out of larger urban centres and owned by wealthy consortiums of boat owners (Diegues 1983). 
Although policy incentives were aimed towards large-scale fishing production, the expansion of the regional fishing economy also created markets and channels for distribution of fish, which coastal communities, such as Ponta Negra, used to their advantage to develop and expand their own fish-based economies. This was the crucial turning point when many small-scale fishers shifted from mainly subsistence to primarily commercial production. The establishment and subsequent development of cercos in Ponta Negra is an example of this process.

\section{Adopting the cerco fishing technology in Ponta Negra (1970s - 1990s)}

Arrival of the Cercos to Ponta Negra Japanese immigrants introduced the cercos to SE Brazil in the 1920s (Mussolini 1980). This type of fishing technology entered Brazil through the coast of São Paulo State, in Saõ Sebastião, and radiated from there to the rest of coastal Brazil, from Santa Catarina State in the South to Rio de Janeiro State in the North (Martins and Perez 2008; Vianna 2008). Japanese immigration and the spreading of cerco technology were related to economic incentives provided by the Brazilian government to boost the incipient fishing industry at the time (Diegues 1983; Mussolini 1980).

Initially, the cerco fishery was not intended for local fishers from rural areas in São Paulo and Rio de Janeiro (Mussolini 1980). Because of the high costs involved in building and maintaining the cercos and the lack of skills, few local fishers from the area were able to enter this fishery, except as waged crewmembers; Japanese immigrants managed and controlled it (Mussolini 1980). The prohibitive cost of entry was likely the main reason why the dispersal of the cerco fishery along the Rio de Janeiro coast occurred slowly. In spite of being only $100 \mathrm{~km}$ away from the first cerco operations, the cercos reached the North side of the Juatinga Peninsula in the early 1940s, brought by a Japanese immigrant that settled in the area (Vianna 2008).

The cercos took even longer to arrive in Ponta Negra. Unlike the cerco operations in the North side of the Juatinga Peninsula, Ponta Negra community members introduced them in the early 1970s (Taken from the interview with Nelson, October 22, 2010). Ponta Negra fishers had learned to manufacture and manage this fishing technology in nearby communities, such as Praia do Sono, and applied their existing knowledge of net making to construct the cercos. The extra income obtained by those who joined the large-scale fishing fleets allowed them to invest in this fishing technology. This was the case for Antonio (September 20, 2010): "My work in large-scale fishing boats allowed me to save enough money to make my own cerco. As I made the cerco, I also made some canoes. That was the time when fishing in Ponta Negra became my main livelihood."

But large-scale fisheries not only gave access to financial resources to Ponta Negra fishers, they also provided them with skills to handle the large-sized nets that were employed in the newly arrived fishery:

When I became a teenager I worked as crew in industrial fishing boats. I did not work for long, only three years. That was an important phase of my life in which I grew a lot and acquired many skills that I could later use in the work with the cercos (Taken from the interview with José 'Bebeu'; October 25, 2010).

Three cercos were established during this period; though they have changed owners, these same cercos, in addition to four newer ones, are still in operation today (Table 1). 
Table 1 History of cerco ownership and current labour patterns

\begin{tabular}{llllll}
\hline ID & $\begin{array}{l}\text { Owners in } \\
\text { the 1970s }\end{array}$ & $\begin{array}{l}\text { Owners } \\
\text { in } \mathbf{1 9 9 4}\end{array}$ & $\begin{array}{l}\text { Owners } \\
\text { in } \mathbf{2 0 1 1}\end{array}$ & $\begin{array}{l}\text { Workers } \\
\text { Net Master }\end{array}$ & Crew \\
\hline 1 & Not in use yet & & Antonio & Sons & Kinship, non kinship \\
2 & Antonio & Antonio & Eliseu & Employee & Non kinship \\
3 & Bonifacio & Vanderlei & Vanderlei & Employee & Non kinship \\
4 & Not in use yet & & Adilson & Self & Kinship \\
5 & Not in use yet & Leontino & Martinho & Self & Kinship \\
6 & Not in use yet & & Martinho & Self & Kinship \\
7 & Claudio & Eliseu & Valdecí & Employee & Non kinship \\
\hline
\end{tabular}

Fishing Predominance and Social Differentiation in Ponta Negra The establishment of the cerco-based fishery brought profound changes to Ponta Negra livelihoods and social structures. The cerco fishery became not only a profitable economic activity but also the main fish source for community members in Ponta Negra. At the beginning of the cerco fishery, the cerco owners used the commodity networks established by industrial fishing to trade the newly available quantities of fish (Taken from the interview with Nelson, October 22, 2010). As fishing boats from Rio de Janeiro came to Ponta Negra to buy fresh fish, drying fish became less important: "By then our practice of drying fish to store and trade started to vanish. Fresh fish could be sold because of the boats. That was a big improvement here" (Taken from the interview with Nelson, October 22, 2010)

As fresh fish could be sold for cash, those participating in the cercos had access to new food items and better construction materials. Rice and beans became the new staples of the community (Taken from the interview with Nadirema, October 23, 2010). Likewise, access to cash generated within the community also accelerated the house improvement process that started with people working for large-scale fishing boats in the 1950s (see above). Building newer and better houses was not only a possibility, but also a priority. José 'Bebeu' (October 25, 2010) attests: "Most of the money I received from the cerco was invested in improving my house. In fact, every time I had leftover money from the monthly expenses I invested that money in improving my house".

The cercos also reorganised social relations by creating and structuring social hierarchies. These became evident in Ponta Negra when the few who could manufacture and manage a cerco gained an advantage in relation to other community members in terms of access to harvesting and commercialising marine resources. Cerco owners were able to build up other assets, which in turn facilitated more control over the cercos fishery, marine resources and, later on, other economic sectors, such as tourism. The investment in tourism assets was tied to the process of house improvement that had started in the 1950s, when people started working in industrial fishing boats. However, by now, people had realised that investing in better housing would allow them to rent the houses during the holidays when tourist visited the community (José 'Bebeu', October 25, 2010). Likewise, some cerco owners were able to buy diesel boats, which were used to collect the cerco catches, transport them to Paraty, and to catch more fish in the nearby areas using long-lines and surface gillnets (Taken from the interview with Nelson, October 22, 2010).

Cerco owners who established a permanent cerco in the limited number of highly productive spots were able to appropriate more economic advantages provided by the 
newly available fishing technology. This resulted in further social-economic differentiation between those with the highly productive cercos and those with less productive cercos or without cerco ownership (Table 2; Figure 3).

As the cerco fishery became established many community members who were not cerco owners became cerco crewmembers. At the time they entered into operation, each cerco ran with a crew of four to five. Between cerco owners and crewmembers, the cercos employed at least fifteen adults of working age in the community at the time of their introduction. Work in a cerco was initially based on kinship, with brothers, sons and occasionally wives and daughters being actively involved (Claudio 'Zeca', January 24, 2010). As a result of family differences, some cerco owners started to recruit more crewmembers outside family circles.

Cerco owners adopted the payment system that had been used across the region since the establishment of the cercos in the 1920s (Mussolini 1980). According to this payment system, which is still in use, the gross production of the cercos is divided into two equal parts: one part for the cerco owner and the other to the crew. With their part, cerco owners pay for the running costs of the cerco, including maintenance of the boats and canoes, nets and other associated costs. The crewmembers' part is divided into equal shares among them. ${ }^{a}$ Working under this system, crewmembers are relatively more vulnerable to changes in cerco revenue and dependent on the cerco owner.

From Land-based to Sea-based Economy The Cercos fishery also changed everyday activities in Ponta Negra, as people reorganised their lives to be able to engage in both terrestrial and marine-based activities. In the 1970s shifting agriculture was still a common practice in the community (Domingos, September 16, 2010). Those involved in both activities had to visit the cercos at least twice a day and between four to five times during the peak of the fishing season. The available time to work in agriculture and to travel to the plots, sometimes kilometres from the beach, was substantially reduced (Taken from the interview with Nelson, October 22, 2010). Even though internal division within households allowed some members to focus on agricultural activities while others focussed on fishing, easier access to store-bought products facilitated by more available cash and enhanced means of transportation contributed to the decline of shifting agriculture and the availability of associated products. People in the community perceived fishing activities to be less demanding than agricultural ones and started preferring to engage in the former rather than the latter: "[...] Then the cerco fishery started. [...]. We started to produce money out of fishing. Fishing meant less work than agriculture" (Claudio 'Zeca', January 24, 2011).

Table 2 Cerco fishing spots in relation to productivity and ownership stability

\begin{tabular}{llll}
\hline Id & Fishing Spot & Productivity* & Ownership Stability \\
\hline 1 & Pedra raiada & ++ & Yes \\
2 & Porto & ++ & Yes \\
3 & Tapicirica & +++ & Yes \\
4 & Pesquero de Salema & +++ & No \\
5 & Paredão & + & No \\
6 & Boquerão de Furado (E) & + & No \\
7 & Saco de Serafim & +++ & Yes \\
\hline
\end{tabular}

*Cerco productivity: low (+), medium (++), high (+++). 


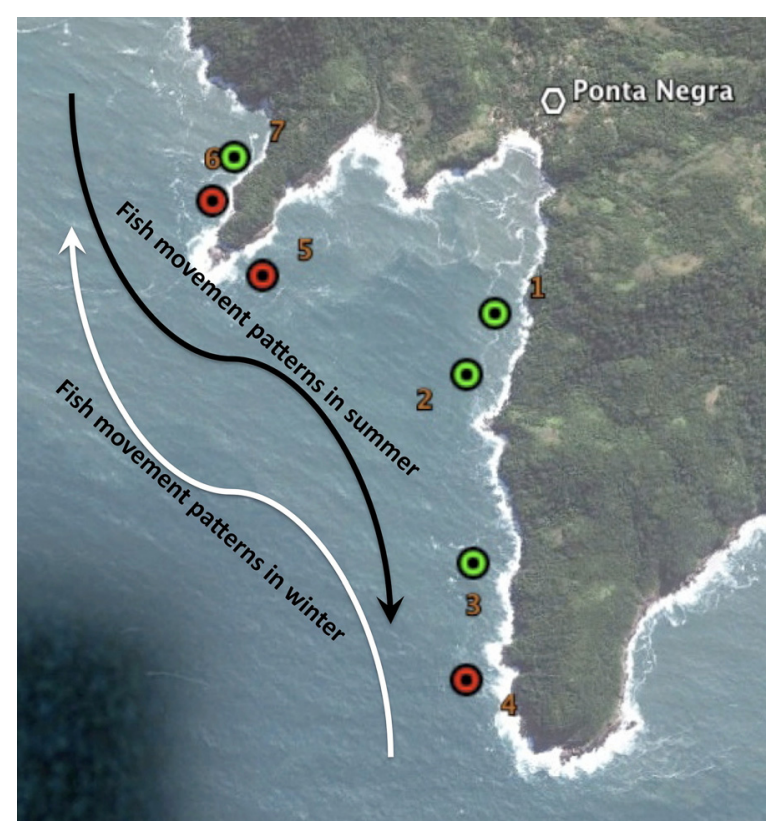

Figure 3 Locations of cerco fishing gear in Ponta Negra (source Google Earth).

Marginalisation within the Regional Fishing Economy Although the cerco fishery gave access to larger amounts of fish and cash than ever before, the Ponta Negra fishing economy remained marginal within the regional context. This was a result of the inability of the cerco fishery to compete with the large-scale fishing sector. Following the modernisation of the industrial fishing (Diegues 2002), large-scale fishing boats flooded the market with large quantities of fish, which resulted in a permanent decline in fish prices. This was exacerbated by the price differential across the fish commodity chain, which, from the 1960's to the present day, has not favoured Ponta Negra fish producers. Today they receive, on average, approximately 20 per cent of the final sale price. While community members sell blue runner (Caranx crysos), one of the most valuable fish caught by Ponta Negra cercos, for 2.00 Brazilian real/Kg (approx. 1.25 US dollars) to fish buyers, the same fish is sold to the final consumer in Rio de Janeiro and Sao Paulo for between 7.00 and 8.00 Brazilian real/Kg (approx. 4.45 and 5.1 US dollars) (Afonso, February 13, 2011). Some of the Ponta Negra fishers who were active in the 1970s mentioned that even though they could catch relatively large amounts of fish, the return they received from their catches was still low:

We caught large quantities of fish, between 5 and 10 tons every two weeks, but we sold it for between 10 and 30 cents of Cruzeiro/Kg. For example, peixe espada [largehead hairtail, Trichiurus lepturus] and carapau [blue runner] were very abundant, yet very cheap. We used to catch tons of fish and sold it for nothing ['troco de nada'], so the fish would not rot (Jose 'Bebeu'; October 25, 2010).

\section{Contemporary dynamics of the Ponta Negra cerco economy (1990s - today)}

Local Manifestations of the Crisis in the Regional Fishing Economy The late 1980s and 1990s came with several local and regional changes that affected Ponta Negra and its cerco fishery activities. Between 1980 and 1995, the fishing sector all across SE Coastal 
Brazil experienced a drastic decline in fish catches (Diegues 2002). ${ }^{\mathrm{b}}$ In Ponta Negra, community elders recalled that in the late 1980s, and the beginning of the 1990s, their catch of fish was so low that they began to question whether fishing was still profitable (Taken from the interview with Nelson, October 22, 2010).

As fishing became unprofitable, boat owners were forced to abandon and/or sell their diesel boats. This hindered access to markets in urban centres for the fish caught in Ponta Negra. By 1994, there were only four boats left in the community, and only two in working condition (Brito 2003). Within less than a decade, all the diesel boats in Ponta Negra were either sold or decommissioned and cerco owners started using less costly fibreglass skiffs as the main means for maritime transportation (Afonso, February 13, 2011). This change in transportation technology changed access to regional markets and services for Ponta Negra community members. However, this change did not happen only because of the decline in the fish catches. It was tied to regional changes, such as road construction and tourism development.

Regional Integration and Tourism Developments The opening of the Rio-Santos Highway, which connected urban centres along the Rio de Janeiro and São Paulo State coastlines and provided road access to the Paraty region at the end of the 1970s (Adams 2000), was another critical factor that impacted the daily lives of Ponta Negra dwellers. Road access made the Atlantic Forest and its adjacent coast accessible to the São Paulo's middle and upper middle class. This triggered aggressive tourism development all over the region, which skyrocketed the value of real estate (Barros, February 7, 2011). One tourism development that particularly affected Ponta Negra was the gated community of Laranjeiras. The construction of this gated community restricted local access to two key beaches in the area. Considering that beaches are public in Brazil, and therefore, by law access cannot be denied, Laranjeiras was required to allowed people from Ponta Negra and other nearby communities to use their marina as an access point for travelling to the Rio-Santos Highway and Paraty (Claudio 'Zeca', January 24, 2011).

The passage through Laranjerias had been available since 1978 (Costa 2009), but it was not until 1995 that it became a conduit for trading fish (Afonso, February 7, 2011). While it was economically viable Ponta Negra cerco owners preferred to use the route around the Juatinga Peninsula to transport fish using diesel boats because it allowed them to bring better quality fish to the markets and find better deals for their catches (Afonso, February 13, 2011). After the aforementioned loss of most of the boats owned in Ponta Negra, the newly available passage through Laranjeiras became a critical transportation hub for people, fish and supplies.

The new route to the city through Laranjeiras, coupled with the shift from diesel boats to fibreglass skiffs as the means for fish transportation, opened a door for commercial fish buyers to become more dominant players in the trade of fish from Ponta Negra (Afonso, February 13, 2011). Fish buyers in the region started a process of vertical integration, gaining control over more aspects of the supply chain (Giesbrecht 2011). Fish buyers started negotiating deals with the cerco owners to send their trucks to Laranjeiras to pick up the cerco catches around 1995 (Afonso, February 13, 2011). Fish buyers became the providers of fuel, ice and other resources necessary for keeping the cercos running in exchange for their monopoly over the purchase of the catches. Cerco owners secured a fixed buyer 
who would always buy their catch at the expense of having to accept any price offered for their product. Antonio (September 20, 2010) reflected upon the outcomes of the commercial relations between fish buyers and local cerco owners:

During the last two decades, during the time we have been dealing with them, fish buyers' businesses have grown. They have been able to buy boats and trucks and to expand their facilities in Paraty. At the same time, we have stayed in the same or perhaps even worse conditions.

Trading the fish catches through Laranjeiras also brings logistical constraints in the delivery of the catch imposed by the management of the gated community. Since the establishment of this site of exchange there have been regular and severe congestion at the dock. The pier at Laranjeiras only has the capacity for mooring one skiff at a time, yet it is intended to serve all the cercos in Ponta Negra and their neighbouring community, Praia do Sono. This logistical limitation causes delays in the unloading, loading and delivery of fish. Sometimes the catches have to wait under the sun for more than five hours before they can be delivered, causing them to lose quality and value (field notes, September 29, 2010). The more time fish is exposed to hot weather and sun, the lower its price becomes (Afonso, February 13, 2011).

The management of Laranjeiras has consistently enforced limitations and constraints on the passage of fish through their premises. In addition to the logistical limitation of only being able to unload one skiff at a time, Laranjeiras also has imposed limited hours to moved fish (from 9:00 am to 5:00 pm, Monday to Friday). Furthermore, every year, between December and January, when the fishing season is starting to peak, the management of Laranjeiras puts a ban on the passage of fish (Conselho da Administração Condominio Laranjeiras 2009). Cerco owners are forced to ground their fishing gear until the ban is over. These conditions have left the Ponta Negra cerco fishery and those associated with it in a disadvantaged position in relation to the regional economy. The fish produced in Ponta Negra, in addition to being sold for low base prices, as a result of the glut of fish on the market because of industrial fishing, depreciates because of the structural limitations that constraint its fair access to the markets.

Structural Limitations for Fish Trade Lack of adequate storage facilities and means of transportation are the main structural limitations that fishers from Ponta Negra face that prevent fair access to the markets. The fish caught by industrial boats in the region is immediately stored in ice and sent either to cold rooms or straight to the markets; it exists within carefully controlled temperature throughout the supply chain (Afonso, February 13, 2011). The fate of Ponta Negra fish catches is different. After being caught from the cercos and landed, fish is stored in Styrofoam boxes with ice brought from Paraty and provided by the fish buyers. The catch stays in storage until enough fish is caught to make a shipment to Laranjeiras worthwhile. This waiting period normally lasts between one and three days. After that, the fish is transferred into lidless, plastic flats, which are used to carry the fish to uncovered skiffs waiting on the beach. The fish is poured from the flats into the bottom of the skiffs. From this point on, the fish is directly exposed to heat and sunlight until it is finally loaded into the fish buyer's trucks at Laranjeiras. Sun exposure sometimes lasts for several hours before the fish is picked up and stored in ice again. During every step the fish is tossed around and bruised, losing value and quality. 
Afonso (February 13, 2011), a fish buyer from Ponta Negra, talks about the treatment that Ponta Negra catches receive and its quality:

The fish from Ponta Negra loses price because it is not stored properly, because it is exposed to sun and heat. When it reaches the market it is already soft and smelly [...]. The fish from Ponta Negra does not have good quality. When you eat it here [in Ponta Negra] it is the best fish. However, by the time it arrives to its final distributor it is tired fish (peixe cansado), not fresh fish (peixe vivo). After they [Ponta Negra cerco owners] started selling fish through Laranjeiras, the quality of the fish dropped.

Cerco Locations and Associated Dynamics Even though the cercos have been in the community for over 40 years, their number has not been stable nor have their owners. Some cercos in the community are better located and hence more productive than others. The limited number of productive spots is tied to the necessary distance between cercos, their position in relation to pelagic schooling fish movement patterns, and protection from bad weather events (Figure 3). Cerco owners provided a qualitative estimation of the productivity of their cercos (Table 2), which can be linked to the stability of their ownership: the cercos with higher productivity have tended to show more stable ownership over the years with the exception of fishing spot 4 .

The most productive cercos in Ponta Negra are 3, 4 and 7. Their productivity is associated with their position on the West side of Ponta and Antigos Bay, which is the summer passage area for high-value migratory pelagic schooling fish, such as king mackerel (Scomberomorus cavalla), Spanish mackerel (Scomberomorus brasiliensis) and blue runner. Although they are on the West side of Ponta Negra Bay, as a result of their position in relation to Antigos Point, schooling fish often by-pass Cercos 1 and 2 and as a result they are not as productive. Cercos 3 and 7 have an advantage over cerco 4 because of their more sheltered positions within the Bays. Cerco 4 is often damaged during bad weather events. The location of a productive cerco is a fine balance between exposure to fish migration routes and protection from damaging waves and currents.

Cerco productivity is also linked to the stability of their ownership. This is evident with cercos 4, 5 and 6, which have frequently changed hands because of their low profitability linked to low-catching power (5 and 6) and high maintenance costs (4). Cerco 4 also has high access costs because of its distance from the Ponta Negra Beach. The owners of the more marginal cercos $(4,5,6)$ have also tried to compensate for the limited productive spots available through innovation and experimentation. For example, the mouth opening of cerco 5 , as mentioned above, is oriented seaward to intercept the winter school migration, which is not as abundant as the summer one.

\section{Territoriality and cerco ownership}

To further analyse how the ownership of the cercos is linked to local territoriality and livelihood diversification in Ponta Negra, dynamics of cerco ownership are examined across three moments in the cercos' history (Table 1). The first moment is in the early 1970s when the cercos were introduced in the community. The second moment is 1994. The data for this mid point is found in Brito (2003). The year 1994 is relevant for the cerco ownership dynamic in the community since it marks the re-organisation of the cercos after the Japanese entrepreneur left the community. The last moment is based on the current owners as of March 2011. Additionally, we take into consideration the current relationships between cerco owners and their respective crews. 
Antonio built cerco 1 after selling cerco 2 to Eliseu around 1995. This was the last cerco with stable ownership built in Ponta Negra Bay. His two sons, who also work in large-scale fishing boats during the winter, currently manage this cerco, which is used only in summer. In addition to the cerco, Antonio's family owns several houses that are rented during the summer holidays. The family also owns two skiffs, which, other than delivering the cerco catches, are used for transporting tourist during the summer holidays.

Antonio built cerco 2 at the time cercos were introduced in Ponta Negra. This cerco was kept under Antonio's management until he sold it to Eliseu, who currently has control over it. In addition to this cerco, Eliseu's family owns several houses, which are rented especially during the summer holidays. Eliseu's family lives in Paraty and his daughters currently attend college in Paraty and Rio de Janeiro. Eliseu and his brother Valdecí, owner of cerco 7, advertise their rental properties through the Internet website administered by their brother, who lives in Paraty and has an extended network that brokers tourism services in Brazil and abroad. Likewise, some of Eliseu's properties are leased to a tourist operator from São Paulo that caters services to clients from São Paulo City and abroad.

Cerco 3 is the most renowned cerco in Ponta Negra because of its size and productivity. It was the first cerco built in Ponta Negra. Bonifacio, its original owner, sold it to the Japanese entrepreneur and then moved to Paraty where he continued buying fish from the community using his diesel boat. Vanderlei took over the management of this cerco after Bonifacio sold it. When the Japanese entrepreneur left the community, Vanderlei took over its ownership. Currently Vanderlei does not work directly in the cerco, devoting his time instead to managing his tourism business. He hires a non-relative from the community to manage his cerco. In addition to cerco 3, Vanderlei's family owns a restaurant and several houses that they rent during the summer holidays. They also own a skiff that is used for freighting cerco catches to Laranjeiras, and transporting tourists. Vanderlei's children live in Paraty where they receive secondary and post-secondary education. Vanderlei's older son is starting to advertise the tourism services catered by his family through the Internet and a travel agency in Rio de Janeiro City that brokers tourism in Brazil and abroad.

Cerco 4 is the most distant cerco from the beach in west Ponta Negra Bay $(\sim 2 \mathrm{Km}$ from shore) and is known in the community for constantly changing owners. Adilson started using this cerco in summer 2010/2011. He moved his gear to this spot after receiving permission from the family of the last users, who are no longer in the community. Adilson and his family live in Ponta Negra. Other than owning cerco 3, Adilson and his family manage cerco 7. They also own a skiff that is used for cerco-related duties and transporting tourists during the summer holidays.

The origins of Cerco 5 are uncertain; nobody in the community remembers when this spot came into use. Leontino, its owner in 1994 (Brito 2003), moved to Paraty in the 2000s. Martinho took over this fishing spot soon after. This is the only cerco in the community that has the mouth open seaward. This innovation is tied to catching schools of winter migrating fish, especially Spanish mackerel.

Martinho built Cerco 6 recently and only uses this cerco spot during the summer. This spot, like cercos 4 and 5 , is exposed to bad weather conditions. Martinho's family owns a diesel boat, which they use for transporting fish to Laranjeiras and for deploying surface gillnets and jigging squid during their respective seasons. Their participation in 
tourism activities is limited because their boat lacks the necessary licence to perform these activities.

Cerco 7 is one of the first cercos built in Ponta Negra, dating back to the introduction of this fishing technique. The maker and original owner, sold this cerco to the Japanese entrepreneur, who hired Eliseu to manage it. Eliseu took over as cerco owner until he sold it to his brother Valdecí. Valdecí hires a non-relative to manage this cerco. Valdecí does not live in Ponta Negra anymore, but keeps active connections with the community. Other than the cerco, Valcecí owns a house that he rents during the holidays. Valdecí also works as a guide for his brother, who caters to foreign tourists doing long hikes in the Juatinga Ecologica Reserve. Valdecí has a son who receives secondary education in Paraty.

\section{Livelihood diversification}

Certain patterns become evident in reviewing the history of each cerco in relation to their location, owners, crewmembers and other community members. Most of the community members who own a cerco also have control over resources in sectors other than fishing. Cerco ownership has resulted in differentiation within Ponta Negra between those who own the means of production and the labourers of the fishery. Cerco ownership has allowed some to control fish resources and appropriate more of the benefits of the catch, providing a surplus that was invested in other economically productive sectors in the community.

Cerco ownership has been a means for social mobility and livelihood diversification. Most of the resources cerco owners have are being used to participate in the tourism sector, which has grown in importance as the fishing sector has dwindled over the last two decades. Likewise, for most of the cerco owners, it has become important to invest in the education of their children outside of the community. This is the first time that a sub-set of community children (that is, children of productive cerco owners) has had access to more education than others who receive only what is provided by the local school.

Many children of the owners of the most productive cercos, some of whom are now young adults, are no longer involved directly in the cerco fishery or in other natural resource-based activities. They have either moved away from the community entirely or have taken on the role of marketing their family businesses, particularly tourism. Literacy and computer skills gained through education outside Ponta Negra have been essential for this transition. This contrasts with the children and other family members of the less productive cercos and community members with no cerco ownership, whose livelihoods depend directly on the cerco fishery, other fishing activities and in the service economy. The options for these children are constrained by their limited educational opportunities, which reflect the economic situation of their families and the poor education available within Ponta Negra.

For those with no assets in the cerco fishery, the cost of augmenting the education level available in Ponta Negra is significant as it necessitates relocation to Paraty or other urban centres. When this happens, not only the child being educated needs to move to the city, but the entire family does as well. This has been the case for many families that have left the community in the past decade. In the urban centres, families tend to face low-skill, poorly paid job opportunities and high costs of living. Often family decision making is focused on addressing short-term needs and the longer-term advantages of investing in education are forfeited. 


\section{Discussion and conclusions}

Livelihood diversification is not new to the inhabitants of SE Coastal Brazil. Prior to the opportunities created by growth in the regional fishing economy throughout the 1900s, local residents had pursued livelihood alternatives afforded by the economic cycles related to sugar cane and coffee production (Adams 2000; Begossi 1996, 2006; Dean 1996). Consequently, coastal peoples in the region have been known to take advantage of economic opportunities as they have presented themselves (Adams 2002). During such periods they have relied less on direct household consumption of local natural resources as they produced commodities for sale in regional markets and had access to store-bought products as a result of their work in the sugarcane and coffee plantations (Adams 2002). Conversely, in times of economic stagnation created by "busts" in commodity markets, they have been known to shift their livelihood strategies towards natural resource-based subsistence (Adams 2002). After the bust of the coffee economic cycle in the late 1800s, the inhabitants of SE coastal Brazil turned to shifting agriculture and fishing to meet the needs of their households (Adams 2000).

Adaptive learning processes associated with previous economic cycles have been shrouded by the passage of time. However, the "boom" in fishing provided an opportunity to document the relationships between individual adaptive learning and livelihood diversification patterns within living memory. While learning related to a new technology has been structured by a regional economy, it has contributed to the structuring of local institutions related to access to natural resources and livelihood diversification.

In Ponta Negra, the adoption of the cerco flutuante fishery led to a process of livelihood specialisation, and in turn, influences future diversification patterns. The opportunity emerges out of the growth in the regional fishing economy and the newly available technology allows some to generate surpluses through the use of that technology. Community members in general associate cercos with an improvement of their quality of life as they provide for increased local employment opportunities. The emergence of such periods of livelihood specialisation is a pattern found in other small-scale fishing systems, in which the access to high-valued resources and the opportunity to trade them have come hand in hand with elevated income (Béné et al. 2003; Coulthard 2008).

Livelihood specialisation also generated social differentiation. Given the physical limitations of Pona Negra Bay, only a few in the community were able to set up productive cercos. In this way, the cercos created socioeconomic categories for community members and their households (that is, cerco owners and non-cerco owners), which had important consequences in the subsequent livelihood diversification patterns. As the regional fishing economy entered into crisis, and the surplus of the cercos shrunk, some cerco owners began to use their financial capital and the intellectual capital gained by family members to diversify through investment in the tourism sector. While the cerco owners and their close relatives adopted a livelihood diversification strategy equivalent to "diversification for accumulation", non-cerco owners adopted "diversification for survival" (Béné et al. 2003).

Community livelihoods, therefore, diversified in two distinct yet co-dependant ways. As the effects of the regional fish crisis were experienced in the community, participation in the tourism sector became an opportunity for those who could invest in the sector. Cerco owners were able to move their existing assets into the tourism sector and invest in new ones, such as infrastructure for restaurants. Non-cerco owners, on the other hand, came to depend on the cerco owners not only in the fishing sector but also in the tourism sector. 
Livelihood diversification linked to the cercos is also reaching the next generation in Ponta Negra. The secondary and post-secondary education opportunities obtained by the children of cerco owners have also been mobilised to support their families' engagements in tourism through the use of new media technologies, especially Internet, unavailable to other community members. This new generation is growing up removed from everyday fishing activities and currently lives in urban centres, where they are removed from the structural limitations (such as the lack of educational opportunities) restricting livelihood opportunities in Ponta Negra. While diversification for accumulation has also facilitated the process by which people's livelihoods do not depend directly on the natural resource-base, diversification for survival has strengthened dependence on natural resources as part of people's livelihood basket, increased dependence on cerco owners and limited livelihood opportunities for the coming generations. Investing in children's education as a strategy to increase longterm capabilities is frequently found in rural contexts, where the access to education beyond post-elementary levels is a perceived necessity, yet is limited to those with the assets or the social networks necessary to support children in urban settings (Bebbington et al. 2007).

Throughout the history of Ponta Negra fish has been perceived as a resource in multiple ways. Before the cercos and the boom of the industrial fishing sector, fish was a marginal component of Ponta Negra livelihoods. As the fishing sector grew, fish was transformed into cash that provided access to better housing and a more diverse diet. Fish prices fell at the same that time dependency on the cerco fishery and store-bought commodities grew. Consequently, fish has come to mean, using the words of a cerco crewmember: "a lot of work, but no money".

As a result of Ponta Negra's disadvantaged position within the regional economy, the community as a whole experiences poverty expressed in low and variable income, lack of basic services and low organisational capacity. The effects of poverty, however, are disproportionally distributed across the community. Having or not having ownership of a productive cerco became strongly correlated with control over the natural resource base and the multiple dimensions in which these resources can be appropriated. While owners were able to accumulate financial capital and invested it in other resources (including the education of their offspring), crewmembers became dependent on cerco owners and proportionally more vulnerable to environmental uncertainty and variation in the fish market. The history of cercos flutuantes in Ponta Negra from the perspective of its users and beneficiaries provides an example of a process by which the introduction of a new technology has tied individual innovation to the boom and bust of the regional fishing economy.

Describing livelihood diversification processes in Ponta Negra through restorying the life history of some of its community members reveals a process by which adaptive learning (Davidson-Hunt 2006) related to a new technology is rooted in individual innovation that in turn can lead to the emergence of new local institutions for natural resource management through the everyday dynamics of a fishing community. The regional economy and the limited number of fishing spots available in the Ponta Negra Bay structured the adoption of the cercos flutuantes in Ponta Negra by a limited number of individuals. Individuals from the community gained both the financial and intellectual capital through their participation in the regional fishing industry to establish cercos in 
Ponta Negra. Those who could establish cercos earlier were able to have access to the most productive fishing spots. Later on they were able to extend their control over other economic sectors as new opportunities emerged. Some elements of the relationships between these processes are more apparent and recognised by research participants than others. For example, it is very common for people to mention that their lives have improved over that last decades in the community because of the income that fishing activities have provided. However, the connection between the adoption of the cercos and social differentiation has been obscured by the normalcy of daily life and the passage of time. Some people acknowledge that there are better off families in the community, but do not provide clear explanation about the origin of these differences.

Our case shows how both local and regional forces continually shape adaptive learning processes. The relationships between these can be understood using elements from Bourdieu's theory of practice: field, practice and habitus. The cerco flutuante fishing technology represents the field, as it is the means by which fish became commercialised in Ponta Negra. Practice can be understood as the social and economic activities performed everyday around the cercos. This includes the operation of the fishing gear, the interactions among owners, crewmembers, and other members of the community, as well as other interactions among fish buyers and other agents involved in the fish trade and its supply chain. The interaction between field and practice has generated a habitus reflecting the historical emergence of structures. These structures dictate who has had access to the surplus generated through selling fish in the regional market and hence have structured social differentiation processes and subsequent livelihood diversification strategies.

Established out of individual adaptation (cercos flutuantes), which is dependent on a particular resource (pelagic schooling fish) and limited locations, the adoption of a new technology resulted in re-structured socio-economic relations within the local fishing sector. The financial capital appropriated from this new field of practice by the owners of the technology allowed some to invest in educational opportunities for their families that open up new opportunities for livelihood diversification in the tourism sector. Interestingly the establishment of new front beach restaurants is also a limited resource that provided cerco owners (or their relatives) with an early foothold during the initial establishment of the tourism sector in the community. This case demonstrates that the conditions of social differentiation are provided when a technological adaptation is applied to resources in a context of limited access. Livelihood diversification through the adoption of cerco technology was not the rising tide that lifted all the boats, rather one that lifted some and sank others.

\section{Endnotes}

a When a cerco owner also works in the cerco, he receives an equal share of the crew's part in addition to the one he receives as the owner.

b This decline was related to unregulated fishing that had started in 1967. Primary culprits in this decline were purse seiners targeting schooling epipelagic species without a quota system (Diegues 2002). 
like to thank the International Opportunities Fund (IOF) from the Social Sciences and Humanities Research Council (SSHRC), Canada (PI, lain Davidson-Hunt); the research program "Community-based resource management and food security in Coastal Brazil", funded by the International Development Research Centre (IDRC), Canada (PI, Alpina Begossi and Fikret Berkes) for providing funding for the field work upon which this paper draws. C.J. Idrobo has also received funding from the University of Manitoba Graduate Fellowship program. His participation in the MARE 2011 Conference was made possible by financial support from the IOF program from SSHRC, and the Faculty of Graduate Studies, the University of Manitoba Graduate Students Association and the Natural Resources Institute, at the University of Manitoba. We would also like to thank Derek Johnson and Katherine Turner for their contributions in the development of this manuscript.

Received: 25 April 2012 Accepted: 6 June 2012 Published: 6 June 2012

\section{References}

Adams, C. 2000. As populaçōes caiçaras e o mito do bom selvagem: a necessidade de uma nova abordagem interdisciplinar. Revista de Antropologia 43(1): 145-182.

Adams, C. 2002. Caiçaras na Mata Atlântica. Pesquisa cientifica versus planejamento e gestão ambiental. Sao Paulo: Annablume. Bebbington, A., L. Hinojosa-Valencia, D. Muñoz, and R.E. Rojas Lizarazú. 2007. Livelihoods and resources accessing in the Andes: Desencuentros in theory and practice. In Wellbeing in Developing Countries: From Theory to Research, ed. I. Gough and J.A. McGregor, 176-198. Cambridge: Cambridge University Press.

Begossi, A. 1996. The fishers and buyers from Búzios Island (Brazil): Kin ties and modes of production. Ciência e Cultura 48: 142-147.

Begossi, A. 2006. The ethnoecology of Caiçara metapopulations (Atlantic Forest, Brazil): ecological concepts and questions. Journal of Ethnobiology and Ethnomedicine 2: 40.

Béné, C. 2011. Poverty in small-scale fisheries: old issue, new analysis. Progress in Development Studies 11(2): 119-144.

Béné, C., K. Mindjimba, E. Belal, T. Jolley, and A. Neiland. 2003. Inland fisheries, tenure systems and livelihood diversification in Africa: The case of the Yaere floodplains in Lake Chad Basin. African Studies 62(2): 187-212.

Brito, M.C.W. 2003. Unidades de Conservação: Intenções e resultados. São Paulo: Annablume.

Conselho da Administraçao Condominio Laranjeiras. 2009. A Palavra do Conselho: Nota do Conselho (Maio). Paraty: Condominio Laranjeiras.

Costa, A.M.M. 2009. Condominio Laranjeiras vs Praia do Sono Processo Administrativo 1.30.014.000016. Angra dos Reis: Procuradoria da República no Município.

Coulthard, S. 2008. Adapting to environmental change in artisanal fisheries-Insights from a South Indian Lagoon. Global Environmental Change 18: 479-489.

Davidson-Hunt, I.J. 2006. Adaptive learning networks: developing resource management knowledge through social learning forums. Human Ecology 34(4): 593-614.

Davidson-Hunt, I.J., and F. Berkes. 2003. Nature and society through the lens of resilience: toward a human-in-ecosystem perspective. In Navigating Social-Ecological Systems: Building Resilience for Complexity and Change, ed. F. Berkes, J. Colding, and C. Folke, 53-82. Cambridge: Cambridge University Press.

Dean. 1996. With Broadax and Firebrand: Destruction of the Brazilian Atlantic Forest. Berkeley: University of California Press. Diegues, A.C. 1983. Pescadores, Camponeses e Trabalhadores do Mar. São Paulo: Ática.

Diegues, A.C. 2002. Sea tenure, traditional knowledge and management among Brazilian artisanal fishermen (Working Paper). São Paulo: University of São Paulo.

Diegues, A.C. 2004. A Pesca Construindo Sociedades. São Paulo: NUPAUB-USP.

Diegues, A.C., and P. Nogara. 2005. Nosso Lugar Virou Parque, 3rd ed. São Paulo: NUPAUB-USP.

Ellis, F. 1998. Household strategies and rural livelihood diversification. Journal of Development Studies 35(1): 1-38.

Ellis, F. 2000. The Determinants of Rural Livelihood Diversification in Developing Countries. Journal of Agricultural Economics 51(2): 289-302.

Ellen, R. 1982. Environment, Subsistence and System: The Ecology of Small-Scale Social Formations. Cambridge: Cambridge University Press.

Ellis, F., and E. Allison. 2004. Livelihood diversification and natural resource access. LSP Working Paper 9: 50.

Giddens, A. 1979. Central problems in Social Theory: Action, Structure and Contradiction in Social Analysis. London: Macmillan.

Giesbrecht, D. 2011. Small-scale Fisher Livelihood Strategies and the Role of Credit in Paraty. Brazil. Master's thesis. Winnipeg: Natural Resources Institute, University of Manitoba.

Hay, I. 2005. Qualitative research methods in human geography, 2nd edition. Oxford: Oxford University Press. Jenkins, R. 2002. Pierre Bourdieu, Revised Edition. New York: Routledge.

Jones, A., and J.T. Murphy. 2010. Theorizing practice in economic geography: Foundations, challenges and possibilities. Progress in Human Geography 35(3): 366-392.

Marschke, M., and F. Berkes. 2006. Exploring strategies that build livelihood resilience: a case from Cambodia. Ecology and Society $11(1): 42$.

Martins, R.S., and J.A.A. Perez. 2008. Artisanal fish-trap fishery around Santa Catarina island during spring/summer: characteristics, species interactions and the influence of the winds on the catches. Boletim do Instituto de Pesca 34(3): 413-423.

Mussolini, G. 1980. Essaios de Antropología Indigena e Caiçara. Rio de Janeiro: Paz e Terra.

Ollerenshaw, J.A., and J.W. Creswell. 2002. Narrative research: A comparison of two restorying data analysis approaches. Qualitative Inquiry 8(3): 329-347.

Tierney, W.G. 2009. Globalization and life history research: fragments of a life foretold. International Journal of Qualitative Studies in Education 23(2): 129-146.

Vianna, L.P. 2008. De invisíveis a protagonistas: Populações tradicionais e unidades de conservação. São Paulo: Annablume. Von Brandt, A. 1972. Fish Catching Methods of the World: revised and enlarged edition. West Byfleet: Fishing News Ltd.

doi: $10.1186 / 2212-9790-11-3$

Cite this article as: Idrobo and Davidson-Hunt: Adaptive learning, technological innovation and livelihood diversification: the adoption of pound nets in Rio de Janeiro State, Brazil. Maritime Studies 2012 11:3. 